Rev. Saúde públ., S. Paulo, 18(6), 1984

\title{
Notícias/News
}

\section{Cinqüentenário da Criação da Universidade de São Paulo}

A Faculdade de Saúde Pública prestou homenagem ao Dr. Christiano Altenfelder Silva, fundador ainda vivo da USP, com uma "Exposição Comemorativa do Cinqüentenário da Criação da Universidade de São Paulo".

Nascido em São Carlos no dia 15 de fevereiro de 1889, al estudou as primeiras letras. Bacharelou-se em Ciências Jurídicas e Sociais pela Faculdade de Direito de São Paulo, tendo pertencido à turma de formandos a quem Rui Barbosa, como paraninfo, dedicou sua "Oração aos Moços".

Durante sua carreira política e administrativa teve a ocasião de participar, em 1930, do Gabinete do Secretário do Interior, José Carlos de Macedo Soares, tendo sido nomeado Membro da Comissáo Organizadora e Diretor da Municipalidade, órgão de administração que então se criou em São Paulo. Este foi adotado posteriormente nos demais Estados, ten. do suas normas dado origem a leis sobre organização de municípios.

No governo Armando de Salles Oliveira exerceu os cargos de Secretário da Educação e Saúde Pública, Chefe de Polícia, Secretário da Justiça e Segurança Pública. Entre os serviços prestados durante sua gestão na Secretaria da Educação, destacou-se a fundação, em 1934, da Universidade de Săo Paulo, passo decisivo no desenvolvimento e na consolidação do ensino superior no Estado.

A exposição constou de documentos, recortes de jornais e fotografias da época em que a USP foi fundada.

Na mostra encontrava-se a cópia oficial do original do decreto da fundação, assinado pelo então interventor federal no Estado de São Paulo, Armando de Salles Oliveira e seu Secretário de Educação e Saúde Pública, Christiano Altenfelder Silva. Também foram expostos o título de Doutor Honoris Causa, conferido em 1936 pela USP a Altenfelder Silva em reco. nhecimento dos serviços prestados na organizaçăo da Faculdade de Filosofia e a "Légion d'Honneur" com que foi agraciado pelo governo francês.

Expuseram-se ainda fotografias históricas como a da primeira Reitoria da USP (o primeiro Reitor foi Reynald Porchat), assim como a ata da reuniáo do Rotary Club de São Paulo de 19 de julho de 1929, quando o fundador da Faculdade de Saúde Pública, Prof. Geraldo Horácio Paula Souza, defendeu a criação de uma universidade em São Paulo. 